2017 Vol 1. No II

\title{
PENGELOLAAN KONFLIK, PENDEKATAN HUMANISME
}

\author{
M. Sayuri Rustam
}

\begin{abstract}
Conflicts will always arise in every organization. This occurs because of the different perceptions of each member of the goals to be achieved by the organization, competition and jealousy. The difference in perceptions between these members will bridge the differences in the activity programs that will be carried out by the organization, which in turn will lead to conflicts in the final results achieved. If this happens, the organization will be ineffective.

Competition between organizational members is also one of the causes of conflict. Competition carried out in a healthy, honest and kind manner will provide great benefits for the organization. However, in many cases the competition that occurs is actually carried out in a way that is dishonest, unhealthy and unkind, to pursue purely personal interests and ignore the interests of the organization as a whole. As a result, the organization is running lame, because one member actually tackles other members for the sake of their individual interests.

Jealousy of the good fortune between members is also a trigger for conflict. This jealousy may very well be triggered by unfair treatment by the leadership of the organization. Therefore, the attitude and behavior of organizational leaders must reflect the principle of justice for all members of the organization and take policies that can provide satisfaction to all parties.

The best solution to this conflict is a win-win solution. This means that the parties to the conflict must be given the best solution so that they do not feel worse than others. Thus, the conflict is not prolonged and can be resolved immediately with a final solution that benefits all parties
\end{abstract}

Keywords: Conflict, Approach, Humanism, Win-win solution, organization. 


\section{Vol 1. No II}

\section{PENDAHULUAN}

Konflik akan selalu muncul dalam setiap organisasi. Organisasi di sini harus dipandang dalam artian yang sangat luas, masyarakat, misalnya. Dalam sebuah organisasi bernama masyarakat, heteroginitas adalah ciri utamanya (Cohen, 1999, p. 14). Artinya, kemajemukan dalam masyarakat adalah indikator utama dari sebuah organisasi bernama masyarakat ini. Akibat dari adanya kemajemukan ini maka ada berbagai ide yang muncul dari padanya. Ide ini juga akan muncul secara majemuk (Ben Anderson, 2001, p. 235). Dengan demikian dalam masyarakat itu akan muncul pluralitas ide. Dalam hal ini, ide-ide yang muncul itu bisa saja saling melengkapi, namun sangat mungkin berbagai ide yang muncul itu bersimpang jalan atau bahkan bertentangan.

Dari sinilah menjadi hal yang sangat krusial bagi pimpinan organisasi untuk terlibat secara intens dalam ikut serta menyelesaikan pluralitas ide yang muncul itu. Ini pulalah yang secara mendasar menjadikan sebuah potensi untuk terjadinya konflik. Konflik antar anggota masyarakat yang sangat majemuk ini bisa saja menjadi konflik diam-diam (konflik tahap 1), muncul secara pelan-pelan (konflik tahap 2) dan secara nyata muncul dipermukaan (konflik tahap 3). Dalam hal ini konflik akan diterjemahkan sebagai situasi yang tidak kondusif yang muncul dalam organisasi yang potensial menyebabkan terjadinya pertentangan antara dua kelompok atau lebih (Abraham, 1998, p. 54).

Dari sini bisa dinyatakan bahwa konflik itu sebenarnya berasal dari internal organisasi itu sendiri yang mencuat keluar besar, kalau tidak dikendalikan. Dalam hal ini, potensi konflik yang ada di dalam organisasi tidak selayaknya untuk dibungkam. Namun konflik ini harus dijadikan bahan acuan untuk memajukan organisasi. Sebab, perbedaan pendapat di internal organisasi itu adalah sebuah kemutlakan. Oleh karenanya, perbedaan pendapat yang bisa menyulut konflik ini justru harus disyukuri, karena dengan adanya perbedaan pendapat itu akan bisa dijadikan batu loncatan untuk menggali ide-ide yang lebih banyak. Dengan demikian akan muncul variasi ide yang melukiskan adanya heteroginitas. Heteroginitas ini akan memberikan warna tersendiri bagi organisasi. Karena dengan heteroginitas ide ini menunjukkan bahwa organisasi itu menjadi terasa dinamis. Akhirnya, organisasi berbasis heteroginitas ini berkembang secara harmonis (harmonically developed). 


\section{Vol 1. No II}

Sesuatu yang heterogen itu adalah sesuatu yang dinamis, sebab heteroginitas itu akan menghasilkan pemikiran-pemikiran baru yang berwawasan ke depan (Pranowo, 2002, p. 3). Itulah sebabnya konflik-konflik internal selalu muncul. Konflik-konflik pada tahap 1 yang masih terjadi secara diam-diam ini tidak perlu untuk diredam. Konflik ini justru diberi ruang gerak secara leluasa untuk menghasilkan sebuah sintesa yang menguntungkan organisasi. Ini sesuai dengan teori Marx yang menyatakan bahwa jika ada tesa pasti ada anti tesa. Konflik antara keduanya akan menghasilkan tesa baru yang berbeda sama sekali dengan yang sudah ada (Bullock, 1997, p. 325). Dari sini bisa disadari bahwa konflik itu justru akan menimbulkan hal baru yang bisa digunakan untuk menghadapi masa depan yang lebih kompleks.

Komplektisitas masa depan yang unpredictable ini sebenarnya juga potensial menyebabkan terjadinya konflik. Sebab persepsi anggota organisasi yang satu dengan yang lain itu berbeda. Perbedaannya didasarkan kepada harapan-harapan yang akan dimunculkan untuk menjagaeksistensi, menaikan prestasi atau justru hanya sekedar survive (Subagyo Susanto, 2002, p. 6). Persepsi untuk masa depan yang berbeda antara yang satu dengan yang lain seharusnya dikelola dengan baik untuk menuju sebuah perbaikan keadaan organisasi yang lebih baik. Alasan utama untuk itu adalah bahwa masa depan itu sesuatu yang maya dan sangat sulit untuk diduga.

Karena kondisi hari esok yang maya ini maka akan muncul berbagai penafsiran sesuai dengan selera masing-masing anggota organisasi. Perbedaan penafsiran akan kondisi pada hari esok inilah sebenarnya penyebab utamanya terjadi perbedaan pendapat antar anggota organisasi. Hal ini akan selalu terjadi di setiap organisasi. Dengan demikian, organisasi akan menjadi kancah perdebatan yang sangat seru untuk adu pendapat tentang berbagai kemungkinan yang akan terjadi di masa datang. Masa datang yang sangat tidak pasti ini justru menyangkut kepentingan hidup dan kehidupan seluruh anggota. Itulah sebabnya masing-masing anggota organisasi akan mempertahankan pendapatnya sendiri tentang masa depan sesuai dengan persepsinya sendiri. Dari sini terlihat dengan jelas bahwa kepentingan pribadi masing-masing anggota adalah segala-galanya. Mereka, mungkin dengan sengaja, justru melupakan kepentingan bersama yang telah dirumuskan dalam tujuan bersama yang akan dicapai. Kondisi ini ternyata juga selalu terjadi di setiap organisasi, apapun nama dan bentuknya. 


\section{Vol 1. No II}

\section{PENYEBAB KONFLIK}

Uraian diatas merujuk pada sebuah kenyataan bahwa konflik itu selalu muncul disetiap organisasi. Dengan kata lain tidak ada organisasi yang hidup tanpa konflik. Konsekuensi logisnya adalah konflik merupakan urat nadi dan denyut darah organisasi (Hadad, 1998, p. 6; Stanford, 2000, p. 67). Penyebab utama dari munculnya konflik adalah perbedaan persepsi antar anggota terhadap kondisi, potensi dan tujuan organisasi. Jika persepsi antara anggota bisa disatukan guna menuju tujuan yang sama yang telah disepakati sebelumnya bisa dilakukan, maka konflik tentu tidak akan terjadi.

Di lain pihak, justru perbedaan persepsi antar anggota ini menjadi hal sulit untuk disatukan. Ini terjadi karena perbedaan kepentingan antar anggota selama perjalanan mencapai tujuan tersebut. Perbedaan kepentingan ini kadang-kadang justru sangat menonjol sehingga menjadi perbedaan yang semakin menajam dan nampak di permukaan (konflik tahap 3). Jika hal ini terjadi maka kepentingan pribadi masing-masing anggota menjadi makin menonjol yang berakibat pada terabaikannya kepentingan organisasi. Potensi konflik akibat perbedaan kepentingan masing-masing anggota ini justru yang paling banyak ditemui dalam kehidupan sehari-hari organisasi (Pranowo, 2002, p. VI).

Ilustrasi konflik karena perbedaan kepentingan ini banyak diperoleh diperusahaan yang mempekerjakan sejumlah buruh/karyawan. Jika karyawan ini hanya mengejar kepentingan pribadinya sendiri maka ia akan bekerja seringan-ringannya dengan meminta gaji setinggitingginya sebagai kontra prestasinya. Namun, pengusaha yang menganggap bahwa buruh/karyawan ini adalah faktor produksi maka majikan akan mendayagunakan faktor produksi tersebut seefisien mungkin sehingga mampu menghasilkan sejumlah produk yang sangat besar. Namun karena prinsip dasarnya adalah bahwa buruh adalah faktor produksi maka pengeluaran untuk buruh (gaji harus ditekan serendah mungkin.

Konflik yang muncul karena perbedaan kepentingan ini benar-benar mengabaikan tujuan organisasi yang telah disepakati untuk dicapai. Jika konflik internal antara karyawan dengan perusahaan ini tidak diselesaikan dengan baik maka tujuan perusahaan untuk mencapai laba 


\section{Journal Competency of Business}

\section{Vol 1. No II}

maksimum tentu tidak akan bisa dicapai. Kasus-kasus pemogokan buruh di kota-kota besar adalah ilustrasi betapa rapuhnya kepentingan bersama yang dipicu oleh masing-masing kepentingan individual.

Konflik-konflik sosial yang dipicu oleh kepentingan masing-masing individu dalam masyarakat itu menjadi bagian yang tak terpisahkan dalam kehidupan sehari-hari. Perbedaan kondisi sosial-ekonomi yang sangat tajam antara pihak yang satu dengan pihak yang lain akan mengundang kecemburuan sosial. Strata sosial yang sangat timpang justru sangat potensial untuk menimbulkan konflik horisontal. Jika ada anggota masyarakat yang merupakan pekerja ulet, tangguh, tidak kenal menyerah dan bersedia bekerja apa saja sehingga penghasilannya tinggi dan kaya akan diirikan oleh orang lain. Mereka yang iri ini tidak mau tahu dari mana penghasilan orang-orang kaya ini diperoleh. Mereka hanya tahu bahwa mereka kaya, sementara dirinya miskin. Akibatnya muncullah dikotomi kaya-miskin. Dilain pihak, kedudukan sosial seseorangpun akan sangat potensial untuk memicu konflik. Karena jabatannya di pemerintahan maka kedudukan sosialnya akan menjadi meningkat. Karena mengejar kepentingan pribadinya maka perilakunya berubah. Akibatnya,terjadilah konflik vertikal antara pejabat dan rakyat. Ilustrasinya saat ini adalah banyaknya demonstrasi dari rakyat yang menentang eksistensi dan kebijakan pejabat.

Konflik-konflik sosial lainnya, termasuk konflik antar etnis, konflik antar agama, konflik antara daerah bahkan konflik antar anak-anak muda itu diduga disebabkan oleh kepentingan masing-masing pihak yang terinjak. Rasa tersinggung karena kepentingan pribadi masing-masing pihak yang tersinggung ini kemudian di blow up oleh masing-masing pendukung. Akibatnya, konflik itu menjadi makin membesar dan sangat mungkin menjadi konflik horisontal yang menjadi sangat sulit untuk diredam. Masing-masing pihak sudah membawa dendamnya masingmasing sehingga dendam pribadi menjadi dendam rasial. Kondisi ini adalah kondisi yang sangat berbahaya bagi keutuhan sebuah organisasi.

Ancaman serius bagi keutuhan organisasi akibat konflik ini harus dicegah. Menghapus seluruh potensi konflik rasanya tidak mungkin. Hal yang paling mudah bisa dilakukan adalah mengeliminasi sampai batas minimal potensi konflik itu (Naumoro, 2000, p. 16). Dengan demikian potensi untuk konflik itu tetap ada, karena konflik itu akan menimbulkan pandangan- 


\section{Journal Competency of Business}

\section{Vol 1. No II}

pandangan baru bagi kemajuan organisasi. Namun potensi konflik yang sangat membahayakan organisasi itu harus diredam sampai batas minimal. Ini semata-mata dilakukan agar persaingan prestatif antar anggota yang satu dengan yang lain tetap ada demi tercapainya tujuan organisasi.

Hal yang sangat mendasar yang harus dicatat disini dalam hal konflik internal dalam sebuah organisasi adalah adanya unsur persaingan. Persaingan ini adalah upayamemperebutkan sesuatu dalam konteks waktu dan tempat yang sama atau hampir sama (Blackwell, 1999, p. 345). Unsur positif dari persaingan ini adalah masing-masing pihak akan berusaha dengan cara sebaik mungkin untuk memenangkannya. Jika persaingan itu dilakukan secara jujur, baik dan sehat (fastabihul khairat), maka hasil yang dicapai menjadi akan sangat baik pula. Namun, yang terjadi dilapangan adalah persaingan itu dilakukan dengan cara menghalalkan segala cara. Artinya, persaingan itu dilakukan dengan cara yang tidak sehat, tidak jujur, tidak baik dan asal menjegal, maka muncullah kemudian potensi konflik yang sangat besar dan berbahaya. Jika itu terjadi, maka pimpinan organisasi harus cepat mengambil tindakan antisipatif agar potensi konflik itu tidak di blow up oleh pihak-pihak lain. Ini adalah bagian yang sangat penting yang harus dihadapi oleh pimpinan organisasi. 


\section{Vol 1. No II}

\section{CARA-CARA KONFLIK}

Konflik internal memang sesuatu yang harus diantisipasi. Antisipasi yang perlu dilakukan adalah mencegah potensi konflik itu untuk tidak makin membesar dan menjadi makin terbuka. Konflik yang makin besar dan makin membuka akan mengundang berbagai hal negatif yang tidak dikehendaki. Konflik ini justru akan menyebabkan jalannya roda organisasi menjadi stagnan dan bahkan mungkin menjadi kacau balau. Untuk itulah maka harus dikenali sejak dini cara-cara melakukan konflik itu. Sehingga potensi konflik itu bisa diredam. Beberapa cara melakukan konflik itu adalah: (Peterson, 2001, p. 2).

\section{Gossip.}

Pada konflik tahap awal, maka akan muncul berbagai gossip. Gossip ini akan diarahkan untuk memecah belah solidaritas organisasi. Di permukaan yang nampak adalah sebuah organisasi yang kompak, solid dan berjalan sesuai dengan relnya. Namun, dibawah permukaan aneka gossip yang muncul ini akan memberikan rasa tidak nyaman, rasa curiga dan rasa tidak tenteram. Gossip ini menjadi sangat sulit dicegah perkembangannya. Ia akan menjalar kemana-mana sampai orang mampu membuktikan bahwa itu semua hanya sebuah gossip yang tidak pernah ada bukti kebenarannya.

\section{Agitasi}

Konflik pada tahap awal ini orang juga bisa melakukan agitasi. Agitasi didefinisikan sebagai ajakan-ajakan untuk melakukan kegiatan melawan kebijakan organisasi (Whitaker, 1998, p. 24). Bahaya agitasi ini adalah munculnya keinginan untuk melakukan makar terhadap organisasi. Agitasi ini biasanya dilakukan oleh orang-orang yang kecewa terhadap organisasi atau kecewa terhadap kebijakan organisasi. Agitasi ini juga sangat sulit dicegah jika masih berada dalam tahap awal. Namun, akan menjadi mudah dideteksi jika konflik itu sudah pada tahap ke 3. Sebab, pada konflik tahap 3 ini konfliknya sudah muncul di permukaan sehingga pihak-pihak yang terlibat konflik sudah mulai bermunculan. Pada tahap ini kelompok-kelompok yang terlibat konflik sudah berada pada posisi akan saling menyerang secara terbuka sehingga para agitator ini menjadi sangat mudah untuk dideteksi. 


\section{Vol 1. No II}

\section{Provokasi}

Hampir sama dengan agitasi, provokasi adalah kegiatan yang menganjurkan untuk melawan kebijakan organisasi (Whitaker, 1998, ibid, p. 26). Provokasi ini akan mengarah pada tindakan-tindakan emosional yang bisa mengakibatkan timbulnya kecemburuan sosial antara sesama anggota organisasi. Akibatnya akan muncul kubukubu yang saling curiga. Dalam hal ini maka jalannya organisasi sudah akan berada pada tahap yang sangat membahayakan, karena konflik internal yang terjadi sudah berada di tahap 2. Para provokator ini selalu berusaha agar organisasi menjadi terhenti dan kemudian mereka akan mengambil alih pimpinan organisasi untuk kepentingannya dan kelompoknya.

\section{Terror}

Ancaman baik psikis maupun fisik dilakukan agar anggota organisasi mengikuti kehendak kelompok ini. Ancaman-ancaman teror ini ada yang bersifat dertak sambal (sudiyono, 2002, p. 5) namun ada juga yang dilakukan dengan serius disertai tindakan kekerasan. Ini selalu terjadi pada tahapan konflik tingkat 3. Tindakan terror ini sangat efektif untuk memaksakan kehendak, sebab akan menghasilkan suasana yang menakutkan, mengerikan dan menyudutkan seseorang. Dengan demikian, orang yang terkena terror akan menjadi sangat sulit untuk melawan dan mencari aksi anti terror.

Cara-cara melakukan konflik ini harus dikenali dengan baik agar upaya mencari solusi yang diperlukan menjadi lebih mudah dicerna oleh mereka yang terlibat konflik. Dengan demikian mereka yang terlibat konflik ini menjadi makin menyadari posisi mereka masing-masing sehingga mereka bisa melakukan introspeksi pada dirinya masing-masing. Di samping itu diperlukan pula adanya tingkat penyadaran pada mereka yang terlibat konflik akan komitmennya pada tujuan organisasi. Tujuan organisasi ini seharusnya bisa digunakan untuk mengikat mereka bersedia melakukan kerja bersama untuk mencapai tujuan tersebut.

\section{PENDEKATAN HUMANISME}




\section{Vol 1. No II}

Pendekatan ini merupakan pendekatan terhadap upaya untuk mencari solusi konflik dengan mendasarkan diri pada konsep kemanusiaan (humanistik). Konsep ini menghendaki agar mereka yang terlibat konflik bisa beradu argumentasi dengan kepala dingin sehingga diperoleh kejelasan atas sumber konflik dan kemudian menetapkan jalan keluarnya (Abdalla, 2002, p. 37). Dari pengertian ini dapat disimpulkan bahwa pendekatan humanistik dalam menangani konflik bisa dilakukan tanpa kekerasan. Artinya pihak-pihak yang terlibat dalam konflik ditawarkan sebuah solusi yang bisa menyenangkan semua pihak.

Dalam hal ini mereka yang terlibat konflik dirujukkan kembali pada tujuan organisasi. Tujuan organisasi ini akan menjadi pengikat mereka-mereka yang terlibat konflik (Shuterland, 1999, p. 14). Sebab, keberadaan sebuah organisasi itu hanya bisa diketahui oleh kesamaan tujuan yang hendak dicapai oleh anggota.Dengan demikian, jika tujuan yang hendak dicapai ini sudah bisa didefinisikan dengan jelas dan memperoleh kesamaan persepsi diantara anggotanya, maka solusi atas konflik bisa diperoleh lewat pendekatan humanistik tersebut. Dari sini masing-masing anggota menjadi memiliki beban tanggung jawab untuk menyelesaikan konflik tersebut berdasar garis tujuan organisasi yang telah disepakati. Kesepakatan yang dicapai ini akan menjadi pengikat bagi para anggota untuk secara bersama-sama bergerak mencapai tujuan tersebut. Kebersamaan melalui kesepakatan ini menjadi bagian integral dari pendekatan humanistik di dalam manajemen sumber daya manusia.

Dalam terminologi manajemen sumber daya manusia, pendekatan humanistik ini dilakukan dengan cara menganggap anggota (buruh/karyawan) bukan sebagai faktor produksi yang harus diperas tenaganya sehingga menghasilkan sejumlah produk dengan efisiensi yang sangat tinggi. Namun, mereka ini harus dianggap sebagai asset (kekayaan) yang ikut serta secara aktif memajukan organisasi (Wellington, 1998, p. 16). Inilah sebenarnya kunci dasar pendekatan humanisme untuk mencari alternatif solusi bagi sebuah konflik. Jika masing-masing anggota ini tidak dianggap sebagai faktor produksi, maka mereka akan menganggap bahwa kebersamaan itu merupakan hal yang sangat penting. Kebersamaan ini akan digunakan untuk membagi tugas sesuai dengan bidang keahliannya masing-masing guna mencapai tujuan organisasi itu.

Pendekatan humanisme dalam menyelesaikan konflik ini akan mendorong munculnya solusi yang menguntungkan berbagai pihak (win-win solution). Jika solusi yang ditawarkan 


\section{Vol 1. No II}

menguntungkan berbagai pihak yang terlibat dalam konflik maka jalannya roda organisasi akan menjadi smooth dan di dukung oleh semua pihak. Hal ini akan memberikan keuntungan yang sangat besar bagi organisasi, karena gerak organisasi menjadi terkoordinasi secara integral. Hal ini akan memberikan kemungkinan yang lebih besar bagi tercapainya tujuan organisasi. Sebab, dukungan para anggota sudah akan menjadi faktor penentu dalam upaya untuk mencapai tujuan tersebut.

Pendekatan humanisme mengharapkan bahwa semua anggota organisasi merupakan bagian integral yang tak dapat dipisah-pisahkan dari organisasi. Oleh karenanya, setiap anggota mempunyai peranan yang sama besarnya dengan anggota yang lain di dalam upayanya untuk memajukan organisasi. Ini artinya, tukang sapu dan tukang membuat minuman untuk seluruh slagorde organisasi mempunyai peranan yang sangat penting sepenting peranan ketua atau sekretaris (bahkan komisaris atau direktur). Penghargaan terhadap setiap komponen organisasi secara proporsional akan memberikan rasa bangga yang sulit dihargai dengan apapun. Kebanggan akan pelaksanaan tugas yang diikuti oleh reward baik spiritual maupun material akan memberikan dukungan yang sangat kuat bagi upaya-upaya untuk melakukan kegiatan yang lebih intensif bagi tercapainya tujuan organisasi (Smith, 1998, p. 26). Dengan demikian, konflik tidak perlu terjadi. Seandainya ada konflik pun solusinya akan mudah dicari.

\section{SOLUSI YANG DITAWARKAN}

Mencegah terjadinya konflik, adalah hal yang sangat utama. Ini dilakukan dengan cara mengeliminasi faktor-faktor penyebab konflik. Hal itu bisa dilakukan dengan cara sejak awal pimpinan organisasi berusaha menyamakan visi dan misi organisasi. Kesamaan visi dan misi ini hanya mudah diucapkan, namun menjadi hal yang sulit untuk dilakukan. Betapa tidak, anggota organisasi yang sangat besar menyebabkan munculnya aneka pemikiran yang persepsinya antara yang satu dengan yang lain akan berbeda. Dari sini konflik tingkat awal sudah mulai terasa adanya. Konflik ini bisa saja didiamkan saja sehingga akhirnya mereda dengan sendirinya (Hendricks, 1992, p. 20). Namun, kondisinya tidak selamanya bisa terjadi seperti itu.

Konflik yang dibiarkan begitu saja akan sangat mungkin tidak pernah ada solusi. Artinya, masing-masing pihak yang terlibat tetap akan memendam rasa permusuhan yang justru sangat berbahaya di masa yang akan datang. Karena dengan dipendamnya rasa permusuhan ini akan 


\section{Vol 1. No II}

terjadi akumulasi kekecewaan yang akan berakibat muncul konflik yang lebih besar. Akibatnya konflik berada pada posisi yang sangat rawan untuk muncul dan sangat mungkin justru terjadi konflik yang sangat tinggi sehingga berujung pada kondisi chaos (Heidjrahman dan Suad Husnan, 1990, p. 294).

Oleh karenanya potensi-potensi konflik ini harus diredam sehingga bisa tereliminasi pada tingkatan yang minimal. Untuk itu organisasi harus menghindarkan diri dari sistim clique (kelompok) dari masing-masing anggota organisasi (van Dijk, 1998, p. 231). Kelompokkelompok baik nonformal maupun formal dalam sebuah organisasi memang membawa keuntungan yaitu upaya pelaksanaan program organisasi bisa menjadi lebih terarah. Namun, disisi lain, kelompok-kelompok dalam organisasi ini sangat potensial mengundang konflik, karena masing-masing kelompok akan didominasi oleh kepentingan kelompoknya sendiri. Akibatnya, akan muncul perebutan kekuasaan antara kelompok, persaingan yang tidak sehat dan hidup dengan kecurigaan. Akibatnya, tujuan organisasi menjadi terbengkalai dan tidak ada upaya bersama untuk mencoba menggapainya. Pelurusan usaha pencapaian tujuan menjadi sebuah hal yang mustahil, karena di dalam tubuh organisasi itu sendiri muncul potensi konflik besar yang muncul tanpa solusi yang jelas.

Jika konflik itu masih merupakan potensi dan belum muncul dipermukaan, maka pimpinan organisasi harus mampu mengajak duduk bersama untuk membicarakan beban berat organisasi. Mereka diajak berembug bersama untuk menyatukan visi dan misi organisasi. Dari kesepakatan bersama ini maka jalannya organisasi akan menjadi makin dinamis. Sebab, jika potensi konflik ini tidak bisa diredam dan diupayakan jalan keluarnya maka akan sangat mungkin konflik internal ini akan membesar dan jalannya organisasi menjadi terseok-seok bahkan justru menjadi stagnant (jalan ditempat). Tidak akan ada kemajuan yang bisa dicapai dalam perjalanan organisasi yang stagnant ini.

Namun, jika konflik sudah terjadi dan muncul dipermukaan, maka konflik itu harus dicegah jangan sampai membesar. Konflik ini harus dicarikan solusi agar mereka yang terlibat dalam konflik itu sama-sama merasa senang. Dalam terminologi ilmu manajemen, solusi seperti ini disebut dengan win-win solution (Chen Hui Ming, 2002). Artinya kedua belah pihak merasa dirinya menang. Sebab, jika solusi win-win ini tidak dicapai maka pihak yang kalah akan tetap 


\section{Vol 1. No II}

memendam rasa permusuhan. Pendaman rasa permusuhan ini akan berakibat sangat buruk di kelak kemudian hari. Sebab, rasa permusuhan ini akan bisa timbul setiap saat, sehingga potensi terjadinya konflik ini menjadi makin besar. Jika itu terjadi maka jalannya organisasi akan tersendat-sendat bahkan bisa berhenti sama sekali.

Langkah paling awal yang perlu dilakukan dalam hal ini adalah mengajak duduk bersama pihak-pihak yang terlibat konflik. Masing-masing pihak diminta untuk menyampaikan kronologi peristiwa terjadinya konflik tersebut beserta semua keluhan yang bermuara pada konflik tersebut. Pimpinan, dalam hal ini, harus bersedia menjadi pendengar yang baik. Setelah itu, pimpinan melakukan fact finding. Upaya-upaya untuk menemukan fakta ini bisa dilakukan bersama-sama dengan pihak-pihak yang terlibat dalam konflik. Dari temuan-temuan yang sudah diperoleh ini kemudian dirujukkan kepada berbagai norma dan nilai yang berlaku yang ada dalam organisasi. Pimpinan akan segera menemukan penyimpangan-penyimpangan yang terjadi di kedua belah pihak.untuk itulah maka pimpinan kemudian membuat ketetapan dan keputusan untuk kembali mengacu kepada norma dan nilai yang berlaku di dalam organisasi. Jika memang norma dan nilai yang ada sudah tidak sesuai lagi dengan gerak roda organisasi, maka pimpinan bisa saja menyesuaikan norma dan nilai itu dengan kondisi terbaru organisasi.

Penyesuaian norma dan nilai baru itu harus didasarkan kepada persetujuan pihak-pihak yang terlibat dalam konflik itu. Dengan demikian, kedua belah pihak merasa bahwa dirinya memenangkan konflik ini. Hal ini sangat diperlukan bagi kepentingan jalannya organisasi yang dinamis. Artinya, perubahan-perubahan yang terjadi pada organisasi itu berlangsung secara alami sebagai akibat dari dinamisasi organisasi (Heru Kristanto, 200, p. 29). Dinamisasi organisasi ini bisa terjadi karena adanya konflik internal organisasi yang bisa dikendalikan dengan baik.

Bagi organisasi yang besar, pimpinan harus mampu mengenali potensi konflik yang mungkin terjadi didalamnya.Konflik kepentingan, persaingan dan kecemburuan adalah beberapa hal yang bisa ditengarai bisa mengundang konflik. Untuk itu, pimpinan harus mengenali pula karakteristik konflik yang mungkinterjadi. Membiarkan konflik terjadi dan tanpa mengambil solusi pemecahan konflik dengan harapan konflik akan teredam dengan sendirinya, suatu sat, adalah tindakan yang kurang bijaksana. Sebab, dalam hal ini konflik tersebut justru akan menjadi berkepanjangan. 


\section{Vol 1. No II}

Jika konflik menjadi makin berkepanjangan dan kemudian melibatkan berbagai pihak, baik yang berkompeten maupun tidak, akan menyebabkan jalannya organisasi menjadi kacau dan tak terkendali. Artinya, tujuan organisasi menjadi makin jauh dari jangkauan. Dengan demikian, semua pihak yang terlibat dalam organisasi itu akan dirugikan. Ini adalah hal yang mendasar yang selalu terjadi disetiap konflik. Mereka hanya didorong oleh kepentingan pribadi masingmasing sehingga kepentingan yang lebih besar menjadi terabaikan. Disinilah letak kerugiannya.

Jika masing-masing pihak yang terlibat konflik itu menyadarai bahwa selain kepentingan pribadi, maka ada kepentingan sosial yang lebih besar yang perlu memperoleh perhatian, maka konflik itu seharusnya tidak perlu terjadi. Dengan demikian, pimpinan harus dengan bijaksana menyelesaikan konflik itu dengan basis kepentingan organisasi. Dari sini kegiatan-kegiatan dan program-program organisasi yang sudah menyimpang akan bisa diluruskan kembali. Ini artinya, mereka yang terlibat dalam konflik telah menyadari bahwa kepentingan bersama berada diatas kepentingan individual pihak-pihak yang terlibat dalam konflik. Pelurusan kembali jalannya organisasi setelah terjadinya konflik, merupakan bagian yang paling dasar dari upaya untuk mencari solusi dalam konflik.

Secara konsepsional penyelesaian konflik itu bisa dilakukan dengan beberapa cara antara lain (Sudiyono, ibid):

1. Kompromi. Dalam hal ini mereka-mereka yang terlibat dalam konflik duduk bersama dalam satu meja untuk melakukan pembicaraan-pembicaraan intensif mengenai masalah yang dihadapi. Pembicaraan difokuskan pada masalah yang menjadi penyebab konflik. Arah pembicaraan adalah pada perwujudan penyelesaian masalah konflik dengan mengacu pada kompromi antara berbagai pihak yang terlibat konflik dengan memperhatikan azas win-win slolution.

2. Intermediasi. Jika kompromi sulit dilaksanakan maka diperlukan pihak lain yang netral untuk melakukan intermediasi. Intermediasi ini diperlukan agar masalah yang menjadi pemicu konflik bisa dilihat dengan jernih dan kepala dingin. Para penengah (intermediators) ini bertugas untuk menempatkan porsi masalahnya pada posisi yang benar sehingga bisa dilihat dengan kacamata yang jernih. Dari sini akan diperoleh solusi yang tidak memihak salah satu peserta konflik. 


\section{Journal Competency of Business}

2017 Vol 1. No II

3. Negosiasi. Negosiasi bisa dilakukan antara mereka yang terlibat konflik. Negosiasi ini dilakukan dengan memberikan tawaran-tawaran yang bisa digunakan untuk menyelesaikan konflik. Azas utama dalam negosiasi ini harus menghindarkan diri dari adanya pihak yang kalah dan menang. Dengan demikian azas yang harus digunakan dalam hal ini adalah azas win-win solution.

Oleh karenanya untuk memperoleh solusi yang baik bagi konflik ini harus dirumuskan dengan kepala dingin dan hati yang tenang berdasarkan azas win-win solution. Ini sangat diperlukan agar pihak-pihak yang terlibat konflik bisa dihargai secara manusiawi dan wajar. Dalam hal ini mereka-mereka yang terlibat konflik bisa mendalami dan mengerti posisinya masing-masing sehingga komitmennya yang tinggi pada tujuan organisasi bisa tetap terbina. Ini akan menjadi landasan yang sangat kuat bagi perjalanan organisasi di masa datang agar bisa menjadi lebih lancar. 


\section{Journal Competency of Business}

\section{Vol 1. No II}

\section{KATA AKHIR}

Potensi konflik, akan selalu ada di setiap organisasi. Penyebab utamanya adalah adanya kepentingan pribadi dari masing-masing individu yang ada dalam organisasi, persaingan dan kecemburuan. Pimpinan organisasi harus mampu mengenali penyebab munculnya potensi konflik ini sejak awal. Ini artinya, pimpinan organisasi sudah harus menyiapkan perangkatperangkat antisipatif bagi penanganan konflik yang mungkin muncul di kelak kemudian hari. Hal ini sangat diperlukan agar jalannya organisasi menjadi makin dinamis dan tidak menjadi stagnant akibat konflik.

Mungkin pendapat Amien Rais (2002) perlu mendapat perhatian bahwa perbedaan pendapat itu justru rahmat. Artinya, jadikanlah potensi konflik itu sebagai alat untuk memajukan organisasi. Berbagai perbedaan pendapat yang bisa diakomodasikan dengan baik di dalam sebuah organisasi akan menyebabkan munculnya berbagai faktor penyebab dinamisasi organisasi. Organisasi menjadi makin segar, tumbuh dan berkembang bersama dengan perbedaan pendapat itu. Oleh karenanya silang sengkarut yang terekspresi dalam konflik ini harus disikapi dengan positif sebagai bagian dari upaya untuk memajukan organisasi. 


\section{Journal Competency of Business}

\section{Vol 1. No II}

\section{DAFTAR PUSTAKA}

Abdalla, Alhasan., M, 2002, The theory of conflict; consolidation, integration and solution; Moslem Book, Pakistan.

Amien Rais, 2002, "Perbedaan pendapat itu rahmat", Kedaulatan Rakyat, Yogyakarta, 2 Agustus.

Blackwell, R. N., 1999, Modern Economic Theory, Kent Publishing Co, Sydney.

Cheng Hui Ming, 2002, "How to manage people", Asian Wall Street Journal, Singapore, August.

Cohen, Richard A., 1999, Sociology, an introduction. Homepress, London.

Hadad, M. A, 1998, Modern theory of conflict, Random House Of India, New Delhi.

Heidjrahman Ranupandoyo dan Suad Husnan, Manajemen Personalia, Edisi 4, BPFE, Yogyakarta.

Naumoro, Yoshihara, 2000, Modern Organization, how to reduce confloct. McGraw-Hill-Kogakusha, Tokyo.

Petterson, J. D., 2001, “Several ways of internal conflict in less developed countries”, Journal of Sociology, April.

Pranowo, 2002, “Buruh asset atau faktor produksi?” Kedaulatan Rakyat, Yogyakarta, 14 Februari.

Shuterland, R. N., eds., Organization in internal conflict, McLoyd Publishing Co., New Jersey.

Smith, J. K., 1998, "Improving less developed countries trough social approach". Journal of Sociology, XXXVIII(2), February.

Sudiyono, 2002, “Mengatasi konflik internal, sebuah analisis atas konflik ketenagakerjaan”, makalah seminar, tidak diterbitkan.

Van Dijk, J., 1998, "Regrouping society, an approach to eliminate horizontal conflict. Acase study in South African Society", Journal of Sociology, XXXVII (4), March.

Wellington, D. T., 1998, "social approach to production”, Journal of Industrial Psychology, XXV (6), April.

Whitaker, T. N., 1998, Sociology in modern society, Pinguin Book Co., London. 